\title{
A one-step synthesis of tricyclic pyrimidines
}

\author{
Mirko Bauer and Stefan Spange* \\ Department of Polymer Chemistry, Chemnitz University of Technology, Straße der Nationen 62, \\ 09111 Chemnitz, Germany \\ E-mail: stefan.spange@chemie.tu-chemnitz.de
}

\section{Dedicated to Rainer Beckert on the occasion of his $60^{\text {th }}$ anniversary}

DOI: $\underline{\text { http://dx.doi.org/10.3998/ark.5550190.0013.304 }}$

\begin{abstract}
The reaction of triflic anhydride activated carbonyl compounds with 5-phenylbarbituric acids in a mild, non-catalyzed one-step procedure yields unusual tricyclic pyrano[2,3- $d]$ pyrimidines or oxazolo[3,2-c]pyrimidines containing an ADA hydrogen bond pattern. By subsequent functionalisation, other derivatives are accessible, including for instance a pyrimidine containing phenolphthalein analogue, thereby combining established chromophoric systems with a supramolecular recognition unit.
\end{abstract}

Keywords: Heterocycles, pyrano[2,3-d]pyrimidines, oxazolo[3,2-c]pyrimidines, barbiturates, triarylmethane dyes

\section{Introduction}

Polycyclic compounds containing the pyrimidine system are common biologically active structures, found naturally for example in purine alkaloids or flavine enzymes. They also gained widespread synthetic interest as dyes, ${ }^{1}$ flavine model compounds ${ }^{2-4}$ and due to their various pharmaceutical activities. ${ }^{5-8}$ Many syntheses of such compounds involve metal-catalyzed or multi-step procedures or are restricted to $N, N$-dialkylated pyrimidines. ${ }^{1,6-11}$ Our group previously described the preparation of benzannulated pyrano[2,3- $d]$ pyrimidines from readily available benzophenones and 5-phenylbarbituric acids in a metal-free one-step procedure. ${ }^{12}$ Seeking for dyes capable of supramolecular interactions which may be formed from these compounds, we now present further studies on the scopes and limitations as well as the mechanism of this reaction to prepare substituted tricyclic pyrano[2,3- $d$ ]pyrimidines $\mathbf{1}$ and oxazolo[3,2c]pyrimidines 2 which possess an ADA hydrogen bond pattern at the pyrimidine system. We also show possibilities for a further functionalisation leading to switchable $\mathrm{pH}$-sensitive 
triarylmethane dyes. To our knowledge, molecules with this scaffold are not described yet, although 10-aza-analogues ${ }^{9-11}$ and saturated derivates ${ }^{13}$ of $\mathbf{1}$ are known.

\section{Results and Discussion}

\section{Syntheses}

In general, the reaction takes place between a triflic anhydride $\left(\mathrm{Tf}_{2} \mathrm{O}\right)$ activated carbonyl compound and a 5-phenylbarbituric acid derivative to give isochromenopyrimidines $\mathbf{1}$, as shown in scheme 1 and table 1 . The reaction proceeds smoothly at ambient temperature using benzophenones with electron-withdrawing (entry 1d) or moderately strong electron-donating 1c substituents. When using electron-rich amino substituted compounds, like Michler's ketone, the central pyran ring is opened and stable triarylmethylium cations are formed. ${ }^{12}$ Boronate esters are suitable as well (1f) providing a starting point for further coupling reactions. Benzaldehydes can also be employed with this procedure $(\mathbf{1 a}, \mathbf{b})$, although the reaction then has to be carried out at lower temperatures in order to prevent side reactions. The yields of these reactions are only moderate, but neither a change of the reaction temperature or time nor the variation of the educt ratio lead to an improvement of the yield. However, as usually no by-products are formed it is possible to recover both starting materials during workup. There is also no significant dependence of the reaction rate or yield on the employed benzophenone derivative

There is generally no difference in using 1 - $n$-butyl-5-phenylbarbituric acid $\left(\mathrm{R}^{3}=n\right.$-butyl) or 5-phenylbarbituric acid $\left(\mathrm{R}^{3}=\mathrm{H}\right)$, although the latter is insoluble in dichloromethane and the reaction has to take place in suspension (which can be compensated by longer reaction times). 5(4-Bromophenyl)-barbituric acid, which is obtained by bromination of the phenyl derivative, is also a suitable substrate (1g) offering the possibility of further coupling reactions. However, the more electron-deficient 5-(4-nitrophenyl)-barbituric acid $^{14}$ and the derivatives 1phenylbarbituric acid and 5-ethyl-5-phenylbarbituric acid, where no enol form adjacent to the phenyl ring is possible, could not be converted successfully.

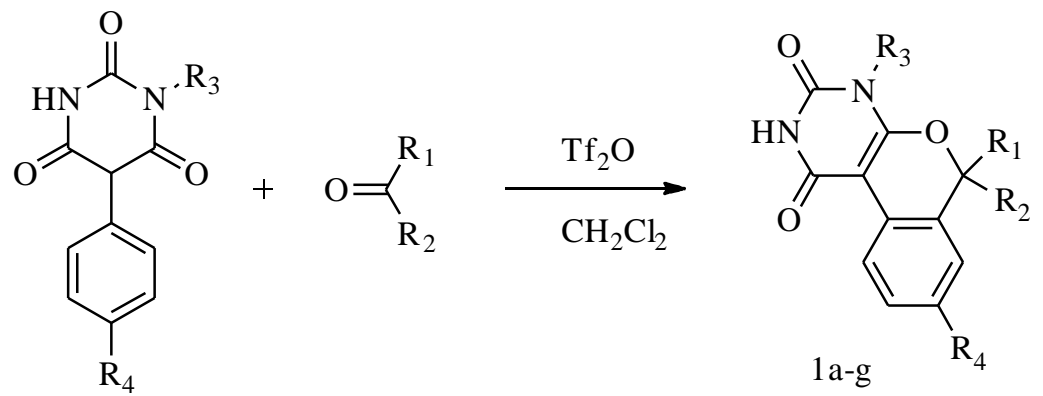

Scheme 1. Synthesis of pyrano[2,3-d]pyrimidines $1 \mathbf{a}-\mathbf{g}$. For the denotation of $\mathrm{R}^{1}, \mathrm{R}^{2}, \mathrm{R}^{3}$ and $\mathrm{R}^{4}$ see Table 1. 
Table 1. Isolated products and reaction conditions of the reaction of activated carbonyl compounds with 5-arylbarbituric acids according to Schemes 1 and 2

\begin{tabular}{llllllll}
\hline Entry & $\mathrm{R}^{1}$ & $\mathrm{R}^{2}$ & $\mathrm{R}^{3}$ & $\mathrm{R}^{4}$ & $\mathrm{~T}\left[{ }^{\circ} \mathrm{C}\right]$ & $\mathrm{t}[\mathrm{h}]$ & yield [\%] \\
\hline $\mathbf{1 a}$ & $\mathrm{Ph}$ & $\mathrm{H}$ & $n-\mathrm{Bu}$ & $\mathrm{H}$ & 0 & 3 & 50 \\
$\mathbf{1 b}$ & $p-\mathrm{C}_{6} \mathrm{H}_{4}-\mathrm{OMe}$ & $\mathrm{H}$ & $n-\mathrm{Bu}$ & $\mathrm{H}$ & -60 & 3 & 20 \\
$\mathbf{1 c}$ & $p-\mathrm{C}_{6} \mathrm{H}_{4}-\mathrm{OMe}$ & $p-\mathrm{C}_{6} \mathrm{H}_{4}-\mathrm{OMe}$ & $\mathrm{H}$ & $\mathrm{H}$ & 20 & 48 & 15 \\
$\mathbf{1 d}$ & $p-\mathrm{C}_{6} \mathrm{H}_{4}-\mathrm{F}$ & $p-\mathrm{C}_{6} \mathrm{H}_{4}-\mathrm{F}$ & $\mathrm{H}$ & $\mathrm{H}$ & 20 & 48 & 23 \\
$\mathbf{1 e}$ & $p-\mathrm{C}_{6} \mathrm{H}_{4}-\mathrm{Cl}$ & $p-\mathrm{C}_{6} \mathrm{H}_{4}-\mathrm{Cl}$ & $\mathrm{H}$ & $\mathrm{H}$ & 20 & 48 & 20 \\
$\mathbf{1 f}$ & $p-\mathrm{C}_{6} \mathrm{H}_{4}-\mathrm{Bpin}{ }^{\mathrm{a}}$ & $\mathrm{Ph}$ & $\mathrm{H}$ & $\mathrm{H}$ & 20 & 48 & 16 \\
$\mathbf{1 g}$ & $p-\mathrm{C}_{6} \mathrm{H}_{4}-\mathrm{Me}$ & $p-\mathrm{C}_{6} \mathrm{H}_{4}-\mathrm{Me}$ & $\mathrm{H}$ & $\mathrm{Br}$ & 20 & 48 & 16 \\
$\mathbf{2 a}$ & - & - & $n-\mathrm{Bu}$ & $\mathrm{H}$ & 40 & 3 & 6 \\
2b & - & - & $\mathrm{H}$ & $\mathrm{H}$ & 40 & 11 & 3 \\
\hline
\end{tabular}

${ }^{\mathrm{a}}$ Bpin $=$ boronic acid pinacol ester.

The use of cyclic ketones, such as xanthone or coumarine, was expected to give spirocyclic compounds but yielded complex product mixtures which could not be separated. However, when tropone is used as the carbonyl compound the oxazolo[3,2-c]pyrimidines $\mathbf{2}$ can be separated from unidentified by-products (Scheme 2). As a large part of the barbituric acid can be recovered unchanged from the reaction mixture, these by-products can probably be attributed to side reactions of tropone. The structure of compounds $\mathbf{2 a}$ and $\mathbf{2 b}$ differs markedly from that of 1a-g. Various NMR techniques such as COSY and HMBC experiments indeed prove the occurrence of a monosubstituted phenyl ring and a 1,7-disubstituted cycloheptatriene moiety attached to one of the pyrimidine nitrogen atoms (see supporting information). While these compounds are stable in pure form, their solutions gradually darken and within several days a dark, scarcely soluble material is separated which could not be identified.

A common feature of these reactions is the possibility of maintaining a triple hydrogen bond pattern similar to flavine which principally enables interactions within biological systems and the incorporation in supramolecular architectures. ${ }^{12}$

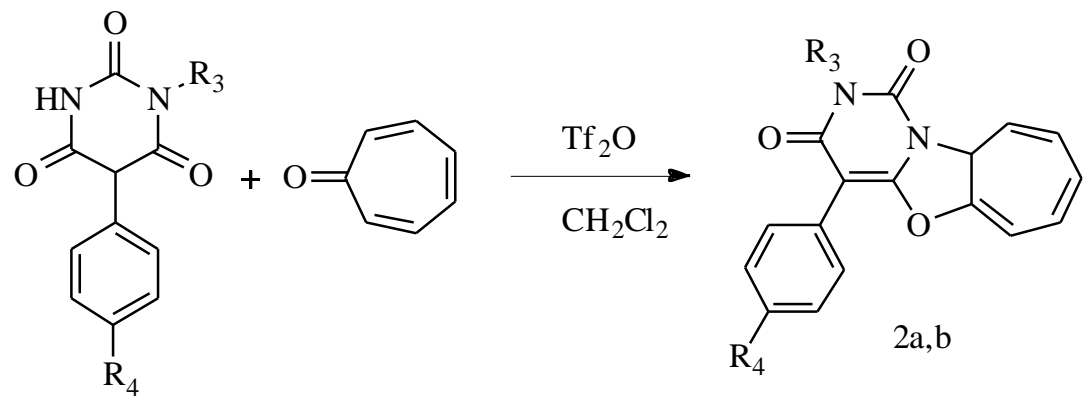

Scheme 2. Synthesis of oxazolo[3,2-c]pyrimidines $\mathbf{2 a , b}$. For the denotation of $\mathrm{R}^{3}$ and $\mathrm{R}^{4}$ see Table 1. 


\section{Mechanistic aspects}

The activation of benzophenones with triflic anhydride leads to the formation of trifluoromethanesulfonyloxy carbenium ions 3-I, whereas in the case of tropone the dication ether 3-II is formed (Scheme 3). ${ }^{15}$ This step can easily be monitored by ${ }^{19} \mathrm{~F}$ NMR spectroscopy where the covalently bound and the anionic triflate show distinct signals. Both, 3-I and 3-II, are very reactive intermediates which react with 5 -arylbarbiturates to give the $O$-alkylated barbiturates $4 .{ }^{16}$ This initial attack proceeds quantitatively, as is indicated by the disappearance of the ${ }^{1} \mathrm{H}$ NMR signal of $\mathrm{H}-5$ of the barbiturate's keto form as well as of the ${ }^{19} \mathrm{~F}$ NMR signal of the covalently bound triflate of 3-I. Representative NMR spectra illustrating these investigations are shown in Figure 1.

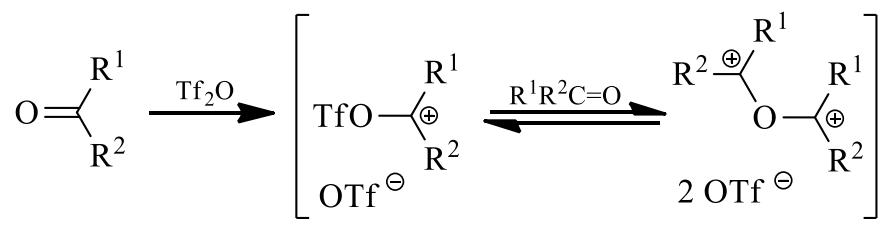

3-I

3-II
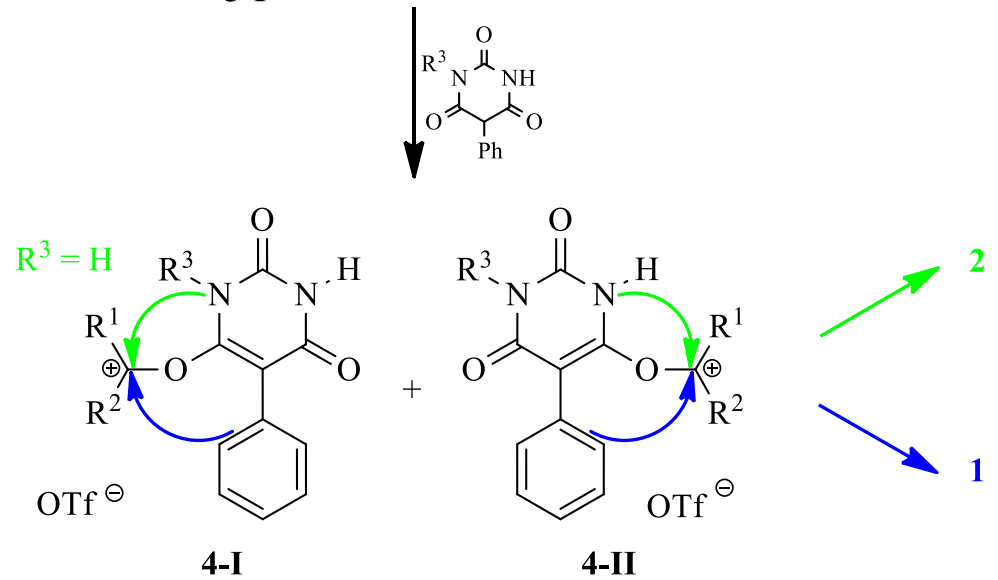

Scheme 3. Proposed mechanism of the formation of $\mathbf{1}$ and 2 . For the denotation of $\mathrm{R}^{1}, \mathrm{R}^{2}, \mathrm{R}^{3}$ and $\mathrm{R}^{4}$ see Table 1 . 


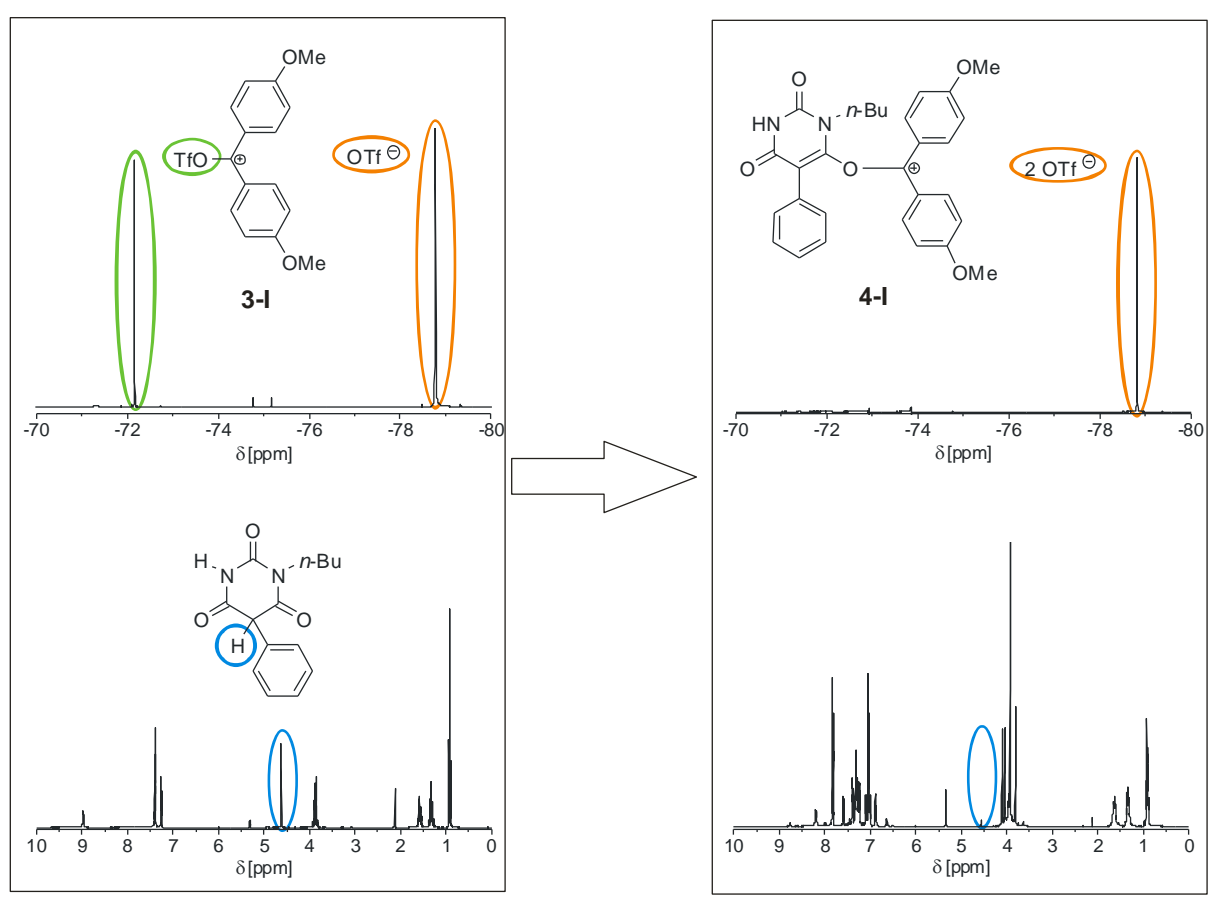

Figure 1. ${ }^{19} \mathrm{~F}$ NMR (top) and ${ }^{1} \mathrm{H}$ NMR (bottom) spectra of the intermediates $\mathbf{3}$ and $\mathbf{4}$ of the reaction of 4,4'-dimethoxybenzophenone with 1-n-butyl-5-phenylbarbituric acid in $\mathrm{CD}_{2} \mathrm{Cl}_{2}$.

Principally, two regioisomeric $O$-alkylation products may be formed in this step, namely 4-I and 4-II, whereby the regioselectivity of the final product is also defined. Obviously, these isomers can only be distinguished when an unsymmetrical, i. e. mono- $N$-alkylated, barbituric acid is used. The ratio of 4-I and 4-II is dependent on the reactivity of both substrates. In general, the electron-donating effect of the $N$-n-butyl group induces a higher nucleophilicity of the adjacent carbonyl group (C-6). Therefore, the reaction with less reactive electrophiles, like those formed from benzophenones, takes place solely at the $N$-alkylated side and yields selectively the $1-n$-butyl substituted products $1 .^{12}$ In contrast, when the respective barbiturate anion is used the negative charge is distributed equally among the carbonyl groups at C-4 and C-6 which are then activated similarly. Thus, the selectivity is diminished and a 1:1 mixture of the 1- and 3alkylated product is obtained. The same trend is observed when using the more reactive dication ether derived from tropone. Then again the barbituric acid is attacked at both carbonyl groups to yield both 4-I and 4-II and the latter intermediate is able to proceed to form $\mathbf{2 a}$.

A subsequent nucleophilic attack, similar to a Friedel-Crafts alkylation mechanism, occurs from the barbiturate phenyl ring which leads to the ortho substituted products, namely the pyrano[2,3-d]pyrimidines 1a-g. Another possibility is the attack of the adjacent NH moiety. The resulting $\mathrm{N}$-substituted barbiturates could not yet be isolated with the benzophenones and benzaldehydes, probably due to decomposition during aqueous workup giving back the starting materials, but this pathway may account for the rather mediocre yields of the presented 
procedure. The likelihood of this possibility is, however, proved in the reaction with tropone whereby the oxazolo[3,2-c]pyrimidines $\mathbf{2 a}, \mathbf{b}$ are obtained.

\section{Further functionalisation}

In contrast to the tricyclic compound obtained with the moderately strong electron-donating dimethoxybenzophenone, the two dimethylamino groups of Michler's Ketone lead to the exclusive formation of a cationic triarylmethylium dye by opening the central pyran ring. With derivatives lying in between those extremes, e. g. 4,4'-bis(morpholino)benzophenone or 2,2',4,4'-tetramethoxybenzophenone, mixtures of several products are formed which are difficult to separate. A possible approach to overcome this problem is provided by the preparation of the chloroarene 1e and subsequent Buchwald-Hartwig-amination ${ }^{17}$ as is exemplified in the reaction with morpholine (Scheme 4). As expected a weakly acidic solution of $\mathbf{1 h}$ is blue coloured which is typical for triarylmethylium dyes of this kind.

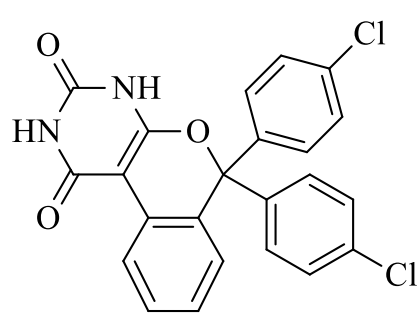

$1 \mathbf{e}$

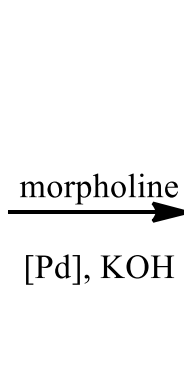

$[\mathrm{Pd}], \mathrm{KOH}$

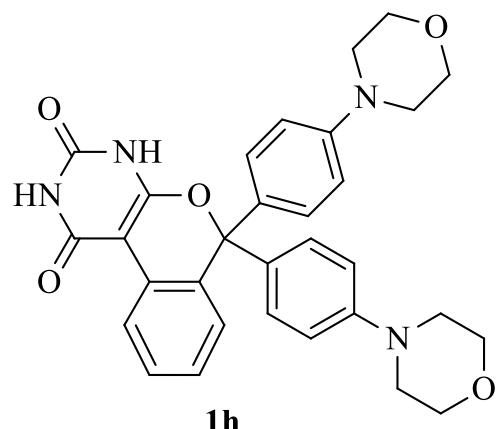

$1 \mathrm{~h}$

Scheme 4. Synthesis of $\mathbf{1 h}$ by Buchwald-Hartwig-amination.

Due to the very high reactivity of triflic anhydride, carbonyl compounds containing an acidic hydrogen are also not suitable for a direct conversion. Advantageously, the demethylation of 1c with acetic acid/hydrogen bromide ${ }^{18}$ provides an easy access to hydroxy-substituted derivatives such as $\mathbf{1 i}$ (Scheme 5) which in turn allows a further functionalisation, e. g. by esterification.
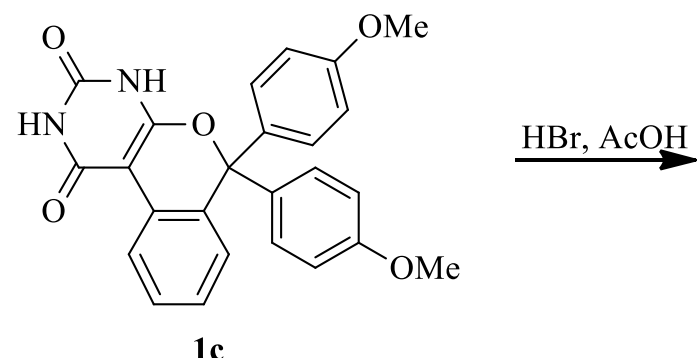

Scheme 5. Synthesis of the phenolphthalein-analogue $\mathbf{1 i}$.

Interestingly, this compound acts as a $\mathrm{pH}$-indicator as its behaviour in alkaline media closely resembles that of phenolphthalein. A UV/vis titration of $\mathbf{1 i}$ in water shows an increasing purple 
colouration resulting from the development of three UV/vis absorption bands when going from $\mathrm{pH}=6.4$ to $\mathrm{pH}=9.5$ (Figure $2 \mathrm{a}$ ). At higher $\mathrm{pH}$ these bands diminish again to give a colourless solution at $\mathrm{pH}>13$ (Figure $2 \mathrm{~b}$ ). The bathochromic shift of the main absorption band from 553 $\mathrm{nm}$ (phenolphthalein) to $572 \mathrm{~nm} \mathrm{1i}$ indicates a strong electron-donating effect of the barbiturate moiety in this chromophore.

a)

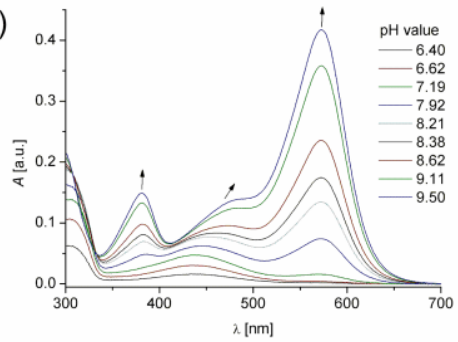

b)

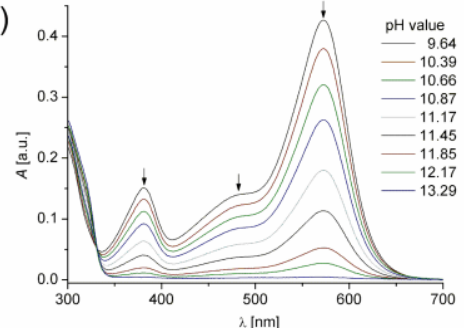

c)

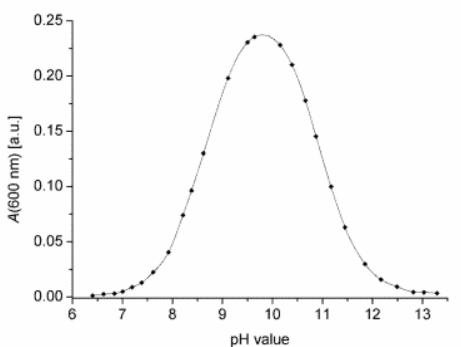

Figure 2. $\mathrm{pH}$-dependent UV/vis titration of 1i; a) spectra at $\mathrm{pH}<9.5$; b) spectra at $\mathrm{pH}>9.5$; c) absorbance at $\lambda=600 \mathrm{~nm}$ as a function of $\mathrm{pH}$.

\section{Conclusions}

Unusual pyrano[2,3- $d$ ]pyrimidines, namely 10-oxa-1,3-diazaphenanthren-2,4-diones, are accessible through a one-step reaction of triflic anhydride activated aromatic carbonyl compounds with 5-phenylbarbituric acids. They can be transformed to triarylmethane dyes possessing an ADA hydrogen bond pattern, for example a $\mathrm{pH}$-sensitive Phenolphthalein-like dye. The analogous reaction with tropone yields an oxazolo[3,2-c]pyrimidines skeleton. The presence of a triple hydrogen bond pattern and various possibilities for a further functionalisation allow the synthesis of potential biologically active compounds or novel dyes combining chromophoric systems with supramolecular recognition.

\section{Experimental Section}

General. 5-Phenylbarbituric acid, 1- $n$-butyl-5-phenylbarbituric acid, ${ }^{14}$ and 4-(4,4,5,5tetramethyl-1,3,2-dioxaborolan-2-yl)-benzophenone ${ }^{19}$ were prepared according to published procedures. Dichloromethane was distilled from calcium hydride, dioxane from sodium/benzophenone. Any other compounds were commercially available and used without further purification. All reactions were carried out under an argon atmosphere.

NMR spectra were obtained on a Bruker Avance 250, a Bruker Avance III 500, or a Varian Inova-400 spectrometer. ${ }^{1} \mathrm{H}$ and ${ }^{13} \mathrm{C} \mathrm{NMR}$ spectra were internally referenced to the solvent signal, ${ }^{19} \mathrm{~F}$ NMR spectra were externally referenced to $\mathrm{CFCl}_{3}$. Elemental analyses were carried 
out using an "Elementanalysator Vario EL" (Elementar Analysengeräte GmbH) or a "Flash EA 112 Series" (Thermo).

For the UV/vis titration, a suspension of $\mathbf{1 i}$ in water was acidified with sulphuric acid to $\mathrm{pH}=$ 6.40. The $\mathrm{pH}$ value was slowly increased by adding small amounts of sodium hydroxide and a $\mathrm{UV} / \mathrm{vis}$ spectrum was recorded after each addition.

\section{Syntheses}

\section{5-(4-Bromophenyl)-barbituric acid}

5-Phenylbarbituric acid $(5.00 \mathrm{~g}, 24.5 \mathrm{mmol})$ was dissolved in $96 \%$ sulphuric acid $(45 \mathrm{~mL})$. At $60{ }^{\circ} \mathrm{C}$ sodium bromide $(3.66 \mathrm{~g}, 35.6 \mathrm{mmol}$ ) was added in small portions over $48 \mathrm{~h}$. After cooling to room temperature the product was precipitated with water, filtrated, washed thoroughly with water and diethyl ether, and finally dried at $150{ }^{\circ} \mathrm{C}$. Colourless solid (85\%); mp: $275{ }^{\circ} \mathrm{C}$ (decomp.); ${ }^{1} \mathrm{H}$ NMR (400 MHz, DMSO- $d_{6}$, mixture of keto and enol tautomers): 5.00 (s, $0.5 \mathrm{H}$ ), $7.25(\mathrm{~d}, J=8.0 \mathrm{~Hz}, 2 \mathrm{H}), 7.53(2 \mathrm{~d}, J=8.0 \mathrm{~Hz}, 2 \mathrm{H}), 10.82(\mathrm{bs}, 0.9 \mathrm{H}), 11.40(\mathrm{bs}, 1.1 \mathrm{H}) ;{ }^{13} \mathrm{C}$ NMR (101 MHz, DMSO-d6): 54.5, 91.4, 119.3, 121.1, 130.6, 131.4, 132.1, 133.3, 133.5, 149.7, 150.9, 161.1, 168.8; Anal. calculated for $\mathrm{C}_{10} \mathrm{H}_{7} \mathrm{BrN}_{2} \mathrm{O}_{3}$ : C 42.43, H 2.49, N 9.90, found: C 42.27, H 2.74, N 9.97; ESI-MS (\%): 283 (57), 285 (53) [M+H] $]^{+}, 565$ (47), 567 (100), 569 (56) $\left[\mathrm{M}_{2}+\mathrm{H}\right]^{+}$.

\section{General procedure for the preparation of (1a-g)}

The carbonyl compound $(5.9 \mathrm{mmol})$ was dissolved in $10 \mathrm{~mL}$ of dichloromethane under an argon atmosphere. Triflic anhydride $(1.0 \mathrm{~mL}, 5.9 \mathrm{mmol})$ was added drop wise at the indicated temperature and after $15 \mathrm{~min}$ the barbituric acid $(5.9 \mathrm{mmol})$ was added. Stirring continued for 3 to $48 \mathrm{~h}$, afterwards $10 \mathrm{~mL}$ of a $10 \%$ aqueous sodium carbonate solution were added and the organic layer was separated and washed twice with water. Finally, the product was precipitated with $n$-hexane and crystallized from acetone/n-hexane or acetone/toluene. Reaction times and temperatures are collected in table 1.

1-n-Butyl-9-phenyl-1,9-dihydro-10-oxa-1,3-diazaphenanthren-2,4-dione (1a) was prepared from benzaldehyde. Colourless solid (50\%); mp: 194-195 ${ }^{\circ} \mathrm{C}$ (decomp.); ${ }^{1} \mathrm{H}$ NMR (250 MHz, $\left.\mathrm{CDCl}_{3}\right): 0.85(\mathrm{t}, J=7.2 \mathrm{~Hz}, 2 \mathrm{H}), 1.26(\mathrm{~m}, 2 \mathrm{H}), 1.32-1.62(\mathrm{~m}, 2 \mathrm{H}), 3.87(\mathrm{t}, J=7.3 \mathrm{~Hz}, 2 \mathrm{H})$, $6.46(\mathrm{~s}, 1 \mathrm{H}), 6.84(\mathrm{~d}, J=7.8 \mathrm{~Hz}, 1 \mathrm{H}), 7.18(\mathrm{t}, J=7.8 \mathrm{~Hz}, 1 \mathrm{H}), 7.29(\mathrm{~m}, 2 \mathrm{H}), 7.40(\mathrm{~m}, 4 \mathrm{H})$, 8.66 (d, $J=7.8 \mathrm{~Hz}, 1 \mathrm{H}), 9.22$ (bs, $1 \mathrm{H}) ;{ }^{13} \mathrm{C} \mathrm{NMR}\left(63 \mathrm{MHz}, \mathrm{CDCl}_{3}\right)$ : 13.6, 19.7, 30.6, 42.0, 83.3, 90.5, 124.0, 125.0, 126.4, 126.5, 127.3, 128.3, 128.9, 129.2, 129.6, 137.0, 149.2, 158.2, 161.2; Anal. calculated for $\mathrm{C}_{21} \mathrm{H}_{20} \mathrm{~N}_{2} \mathrm{O}_{3}$ : C 72.40, H 5.79, N 8.04, found: C 72.33, H 5.89, N 7.67.

\section{1-n-Butyl-9-(4-methoxyphenyl)-1,9-dihydro-10-oxa-1,3-diazaphenanthren-2,4-dione}

was prepared from 4-methoxybenzaldehyde at $-60{ }^{\circ} \mathrm{C}$ for $30 \mathrm{~min}$, slowly warming to $0{ }^{\circ} \mathrm{C}$ within 3 h. Colourless solid (20\%); mp: $178-181{ }^{\circ} \mathrm{C}$ (decomp.); ${ }^{1} \mathrm{H}$ NMR $\left(250 \mathrm{MHz}, \mathrm{CDCl}_{3}\right): 0.85$ (t, $J$ $=7.2 \mathrm{~Hz}, 2 \mathrm{H}), 1.18-1.58(\mathrm{~m}, 4 \mathrm{H}), 3.83(\mathrm{~m}, 5 \mathrm{H}), 6.43(\mathrm{~s}, 1 \mathrm{H}), 6.87(\mathrm{~m}, 3 \mathrm{H}), 7.18(\mathrm{~m}, 3 \mathrm{H})$, $7.39(\mathrm{t}, J=7.8 \mathrm{~Hz}, 1 \mathrm{H}), 8.66(\mathrm{~d}, J=7.8 \mathrm{~Hz}, 1 \mathrm{H}), 9.34(\mathrm{bs}, 1 \mathrm{H}) ;{ }^{13} \mathrm{C} \mathrm{NMR}\left(63 \mathrm{MHz}, \mathrm{CDCl}_{3}\right)$ : 
13.6, 19.7, 30.6, 41.9, 55.3, 83.2, 90.4, 114.2, 124.0, 125.0, 126.4, 126.8, 127.3, 129.05, 129.15, 129.9, 149.2, 158.2, 160.5, 161.2; Anal. calculated for $\mathrm{C}_{22} \mathrm{H}_{22} \mathrm{~N}_{2} \mathrm{O}_{4}$ : C 69.83, H 5.86, N 7.40, found: C 70.02, H 6.08, N 7.14.

9,9-Bis-(4-methoxyphenyl)-1,9-dihydro-10-oxa-1,3-diazaphenanthren-2,4-dione (1c) was prepared from 4,4'-dimethoxybenzophenone. Colourless solid (15\%); mp: 282-284 ${ }^{\circ} \mathrm{C}$ (decomp.); ${ }^{1} \mathrm{H}$ NMR (250 MHz, DMSO-d6): 3.75 (s, $\left.3 \mathrm{H}\right), 6.52$ (d, $\left.J=7.8 \mathrm{~Hz}, 1 \mathrm{H}\right), 6.93$ (d, $J=$ $9.1 \mathrm{~Hz}, 4 \mathrm{H}), 6.99(\mathrm{~d}, J=9.1 \mathrm{~Hz}, 4 \mathrm{H}), 7.15(\mathrm{t}, J=7.8 \mathrm{~Hz}, 1 \mathrm{H}), 7.36(\mathrm{t}, J=7.8 \mathrm{~Hz}, 1 \mathrm{H}), 8.45$ $(\mathrm{d}, J=7.8 \mathrm{~Hz}, 1 \mathrm{H}), 11.02$ (bs, $1 \mathrm{H}), 12.06$ (bs, $1 \mathrm{H}) ;{ }^{13} \mathrm{C}$ NMR (63 MHz, DMSO-d6): 55.1, 88.9, 90.2, 113.5, 122.7, 125.0, 127.0, 127.6, 128.4, 129.3, 131.8, 133.6, 149.1, 158.2, 159.3, 162.0; Anal. calculated for $\mathrm{C}_{25} \mathrm{H}_{20} \mathrm{~N}_{2} \mathrm{O}_{5}: \mathrm{C} 70.08, \mathrm{H} 4.71, \mathrm{~N} 6.54$, found: $\mathrm{C} 69.78, \mathrm{H} 4.37, \mathrm{~N} 6.45$.

9,9-Bis-(4-fluorophenyl)-1,9-dihydro-10-oxa-1,3-diazaphenanthren-2,4-dione (1d) was prepared from 4,4'-difluorobenzophenone. Colourless solid (23\%); mp: $268{ }^{\circ} \mathrm{C}$ (decomp.); ${ }^{1} \mathrm{H}$ NMR (250 MHz, DMSO-d6): 6.53 (d, $J=7.8 \mathrm{~Hz}, 1 \mathrm{H}), 7.08-7.30(\mathrm{~m}, 9 \mathrm{H}), 7.40$ (t, $J=7.8 \mathrm{~Hz}, 1$ $\mathrm{H}), 8.47$ (d, $J=7.8 \mathrm{~Hz}, 1 \mathrm{H}), 11.09$ (bs, $1 \mathrm{H}), 12.15$ (bs, $1 \mathrm{H}) ;{ }^{13} \mathrm{C}$ NMR (63 MHz, DMSO-d6): 88.9, 89.3, 115.3 (d, $J=21.7 \mathrm{~Hz}), 122.9,125.5,126.9,127.5,128.9,130.1$ (d, $J=8.4 \mathrm{~Hz}), 130.9$, $137.6(\mathrm{~d}, J=3.0 \mathrm{~Hz}), 149.1,157.8,162.0,162.1(\mathrm{~d}, J=246.5 \mathrm{~Hz})$; Anal. calculated for $\mathrm{C}_{23} \mathrm{H}_{14} \mathrm{~F}_{2} \mathrm{~N}_{2} \mathrm{O}_{3}$ : C 68.32, H 3.49, N 6.93, found: C 67.66, H 3.62, 6.94.

9,9-Bis-(4-chlorophenyl)-1,9-dihydro-10-oxa-1,3-diazaphenanthren-2,4-dione (1e) was prepared from 4,4'-dichlorobenzophenone. Colourless solid (20\%); mp: $277{ }^{\circ} \mathrm{C}$ (decomp.); ${ }^{1} \mathrm{H}$ NMR (250 MHz, DMSO- $\left.d_{6}\right): 6.54(\mathrm{~d}, J=7.8 \mathrm{~Hz}, 1 \mathrm{H}), 7.11(\mathrm{~d}, J=8.7 \mathrm{~Hz}, 4 \mathrm{H}), 7.19$ (t, $J=7.8$ $\mathrm{Hz}, 1 \mathrm{H}), 7.41$ (t, $J=7.8 \mathrm{~Hz}, 1 \mathrm{H}), 7.50(\mathrm{~d}, J=8.7 \mathrm{~Hz}, 4 \mathrm{H}), 8.47$ (d, $J=7.8 \mathrm{~Hz}, 1 \mathrm{H}), 11.10$ (bs, $1 \mathrm{H}), 12.19$ (bs, $1 \mathrm{H}) ;{ }^{13} \mathrm{C}$ NMR (63 MHz, DMSO-d $)$ : 88.9, 89.1, 122.9, 125.6, 126.9, 127.4, $128.5,129.0,129.7,130.3,133.7,140.1,149.0,157.7,162.0$; Anal. calculated for $\mathrm{C}_{23} \mathrm{H}_{14} \mathrm{Cl}_{2} \mathrm{~N}_{2} \mathrm{O}_{3}$ : C 63.17, H 3.23, N 6.41, found: C 63.20, H 3.20, N 6.16.

\section{9-Phenyl-9-(4-\{4,4,5,5-tetramethyl-1,3,2-dioxaborolan-2-yl $\}$-phenyl)-1,9-dihydro-10-oxa-}

1,3-diazaphenanthren-2,4-dione (1f) was prepared from 4-(4,4,5,5-tetramethyl-1,3,2dioxaborolan-2-yl)-benzophenone. Colourless solid (16\%); mp: $265{ }^{\circ} \mathrm{C}$ (decomp.); ${ }^{1} \mathrm{H}$ NMR (400 MHz, DMSO- $\left.d_{6}\right): 1.28(\mathrm{~s}, 12 \mathrm{H}), 6.51(\mathrm{~d}, J=7.8 \mathrm{~Hz}, 1 \mathrm{H}), 7.08(\mathrm{~m}, 2 \mathrm{H}), 7.13(\mathrm{~d}, J=8.6$ $\mathrm{Hz}, 2 \mathrm{H}), 7.17(\mathrm{t}, J=7.8 \mathrm{~Hz}, 1 \mathrm{H}), 7.40(\mathrm{~m}, 4 \mathrm{H}), 7.69$ (d, $J=8.2 \mathrm{~Hz}, 2 \mathrm{H}), 8.45$ (d, $J=7.8 \mathrm{~Hz}, 1$ H), 11.09 (bs, $1 \mathrm{H}), 12.20$ (bs, $1 \mathrm{H}$ ); ${ }^{13} \mathrm{C}$ NMR (101 MHz, DMSO-d $)$ : 24.7, 83.9, 89.0, 90.1, 122.8, 125.4, 127.1, 127.4, 127.5, 127.9, 128.3, 128.8, 128.9, 131.0, 134.3, 141.3, 144.7, 149.1, 158.1, 162.1; Anal. calculated for $\mathrm{C}_{29} \mathrm{H}_{27} \mathrm{BN}_{2} \mathrm{O}_{5}$ : C 70.46, H 5.51, N 5.67, found: C 70.16, $\mathrm{H}$ 5.57, N 5.45.7-Bromo-9,9-bis-(4-methylphenyl)-1,9-dihydro-10-oxa-1,3-diazaphenanthren2,4-dione (1g) was prepared from 4,4'-dimethylbenzophenone and 5-(4-bromophenyl)-barbituric acid. Light orange solid (16 \%); mp: $293{ }^{\circ} \mathrm{C}$ (decomp.); ${ }^{1} \mathrm{H}$ NMR (250 MHz, DMSO-d6): 2.31 (s, $6 \mathrm{H}), 6.57(\mathrm{~s}, 1 \mathrm{H}), 6.97(\mathrm{~d}, J=7.9 \mathrm{~Hz}, 4 \mathrm{H}), 7.22(\mathrm{~d}, J=7.9 \mathrm{~Hz}, 4 \mathrm{H}), 7.60(\mathrm{~d}, J=8.5 \mathrm{~Hz}, 1 \mathrm{H})$, $8.40(\mathrm{~d}, J=8.5 \mathrm{~Hz}, 1 \mathrm{H}), 11.13$ (bs, $1 \mathrm{H}), 12.25$ (bs, $1 \mathrm{H}) ;{ }^{13} \mathrm{C}$ NMR (63 MHz, DMSO-d6): 20.7 , 88.5, 89.8, 117.7, 124.8, 127.1, 127.8, 129.0, 129.2, 131.6, 133.8, 138.0, 138.5, 149.0, 158.4, 162.0; Anal. calculated for $\mathrm{C}_{25} \mathrm{H}_{19} \mathrm{BrN}_{2} \mathrm{O}_{3}$ : C 63.17, $\mathrm{H} 4.03, \mathrm{~N} 5.89$, found: $\mathrm{C} 63.02, \mathrm{H} \mathrm{4.09,} \mathrm{N}$ 5.95; ESI-MS (\%): 475 (100), $477(98)[\mathrm{M}+\mathrm{H}]^{+}$. 


\section{9,9-Bis-(4-\{morpholin-4-yl\}phenyl)-1,9-dihydro-10-oxa-1,3-diazaphenanthren-2,4-dione}

(1h). A mixture of 1 e $(219 \mathrm{mg}, 0.5 \mathrm{mmol})$, morpholine $(115 \mu \mathrm{L}, 1.3 \mathrm{mmol}), \mathrm{KOH}(168 \mathrm{mg}, 3.0$ mmol) and naphthoquinone-1,3-bis(2,6-diisopropylphenyl)imidazole2-ylidene-palladium(0) (6.5 $\mathrm{mg}, 5.0 \mu \mathrm{mol})$ in $4 \mathrm{~mL}$ of dioxane was heated to $120{ }^{\circ} \mathrm{C}$ for $24 \mathrm{~h}$. The mixture was filtrated through silica and the solvent evaporated. The residue was purified by column chromatography on silica with dichloromethane/ethyl acetate (1:1) as eluent. Pale yellow solid (13 \%); mp: 296$298{ }^{\circ} \mathrm{C}$ (decomp.); ${ }^{1} \mathrm{H}$ NMR (250 MHz, DMSO-d $): 3.12$ (m, $\left.8 \mathrm{H}\right), 3.71(\mathrm{~m}, 8 \mathrm{H}), 6.53$ (d, $J=7.8$ $\mathrm{Hz}, 1 \mathrm{H}), 6.91(\mathrm{~s}, 8 \mathrm{H}), 7.14(\mathrm{t}, J=7.8 \mathrm{~Hz}, 1 \mathrm{H}), 7.34(\mathrm{t}, J=7.8 \mathrm{~Hz}, 1 \mathrm{H}), 8.43(\mathrm{~d}, J=7.8 \mathrm{~Hz}, 1$ $\mathrm{H}), 10.99$ (bs, $1 \mathrm{H}), 12.01$ (bs, $1 \mathrm{H}) ;{ }^{13} \mathrm{C}$ NMR (63 MHz, DMSO- $\left.d_{6}\right)$ : 47.7, 66.0, 88.8, 90.6, 113.9, 122.6, 125.1, 127.0, 127.7, 128.2, 128.8, 131.7, 132.1, 149.1, 150.7, 158.3, 162.1; Anal. calculated for $\mathrm{C}_{31} \mathrm{H}_{30} \mathrm{~N}_{4} \mathrm{O}_{5} * 0.5 \mathrm{H}_{2} \mathrm{O}: \mathrm{C}$ 67.99, $\mathrm{H}$ 5.71, N 10.23, found: $\mathrm{C} 67.65, \mathrm{H}$ 5.37, N 10.15.

9,9-Bis-(4-hydroxyphenyl)-1,9-dihydro-10-oxa-1,3-diazaphenanthren-2,4-dione (1i). A mixture of 1c $(400 \mathrm{mg}, 0.9 \mathrm{mmol})$, glacial acetic acid $(15 \mathrm{~mL})$ and $48 \%$ hydrobromic acid (7 $\mathrm{mL}$ ) was refluxed for $3 \mathrm{~h}$. After cooling to room temperature, the product was precipitated with $100 \mathrm{~mL}$ of water, filtrated and washed thoroughly with water. Finally, the product was precipitated from acetone/toluene. Light yellow solid (90\%); mp: 310-313 ${ }^{\circ} \mathrm{C}$ (decomp.); ${ }^{1} \mathrm{H}$ NMR (250 MHz, DMSO-d6): 6.46 (d, $J=7.8 \mathrm{~Hz}, 1 \mathrm{H}), 6.74(\mathrm{~d}, J=8.8 \mathrm{~Hz}, 4 \mathrm{H}), 6.87$ (d, $J=8.8$ $\mathrm{Hz}, 4 \mathrm{H}), 7.13$ (t, $J=7.8 \mathrm{~Hz}, 1 \mathrm{H}), 7.34$ (t, $J=7.8 \mathrm{~Hz}, 1 \mathrm{H}), 8.44$ (d, $J=7.8 \mathrm{~Hz}, 1 \mathrm{H}), 9.66$ (bs, 2 $\mathrm{H}), 11.01$ (bs, $1 \mathrm{H}), 11.99$ (bs, $1 \mathrm{H}) ;{ }^{13} \mathrm{C}$ NMR (63 MHz, DMSO-d6): 88.8, 90.6, 114.7, 122.6, $125.1,127.0,127.6,128.2,129.4,132.12$, 132.14, 149.1, 157.5, 158.2, 162.1; Anal. calculated for $\mathrm{C}_{23} \mathrm{H}_{16} \mathrm{~N}_{2} \mathrm{O}_{5} * 0.5 \mathrm{H}_{2} \mathrm{O}$ : C 67.48, $\mathrm{H} 4.19, \mathrm{~N}$ 6.84, found: C 68.05, $\mathrm{H}$ 4.11, N 6.92.

\section{4-n-Butyl-6-phenyl-8-oxa-2,4-diaza-tricyclo[7.5.0.0 $\left.{ }^{2,7}\right]$ tetradeca-6,9(10),11,13-tetraene-3,5-} dione (2a). Triflic anhydride $(1.0 \mathrm{~mL}, 5.9 \mathrm{mmol})$ was added drop wise to a solution of tropone $(1.2 \mathrm{~mL}, 12.0 \mathrm{mmol})$ in $15 \mathrm{~mL}$ of dichloromethane. After $5 \mathrm{~min} 1$ - $n$-butyl-5-phenylbarbituric acid (1.541 g, $5.9 \mathrm{mmol})$ was added and the mixture was gently refluxed for $3 \mathrm{~h}$. Then $10 \mathrm{~mL}$ of a $10 \%$ aqueous sodium carbonate solution were added and the organic layer was separated and washed twice with water. The solvent was removed and the residue was purified by column chromatography on silica with dichloromethane as eluent. Yellow oil (6\%); ${ }^{1} \mathrm{H} \mathrm{NMR}(250 \mathrm{MHz}$, acetone- $\left.d_{6}\right)$ : $0.95(\mathrm{t}, J=7.3 \mathrm{~Hz}, 3 \mathrm{H}), 1.37(\mathrm{~m}, 2 \mathrm{H}), 1.63(\mathrm{~m}, 2 \mathrm{H}), 3.95(\mathrm{t}, J=7.3 \mathrm{~Hz}, 2 \mathrm{H}), 4.94$ $(\mathrm{m}, 1 \mathrm{H}), 5.60(\mathrm{dd}, J=2.6,10.0 \mathrm{~Hz}, 1 \mathrm{H}), 6.16(\mathrm{~m}, 1 \mathrm{H}), 6.25(\mathrm{~m}, 1 \mathrm{H}), 6.53(\mathrm{~m}, 2 \mathrm{H}), 7.28(\mathrm{t}, J$ $=7.3 \mathrm{~Hz}, 1 \mathrm{H}), 7.37(\mathrm{t}, J=7.3 \mathrm{~Hz}, 2 \mathrm{H}), 7.54(\mathrm{~d}, J=7.3 \mathrm{~Hz}, 2 \mathrm{H}) ;{ }^{13} \mathrm{C}$ NMR $(63 \mathrm{MHz}$, acetone$\left.d_{6}\right)$ : 14.1, 20.7, 30.70, 41.5, 57.6, 92.1, 101.0, 120.4, 125.9, 127.2, 127.8, 128.6, 129.0, 130.9, $131.2,143.4,148.2,157.1,163.5$.

6-Phenyl-8-oxa-2,4-diaza-tricyclo[7.5.0.0 $\left.{ }^{2,7}\right]$ tetradeca-6,9(10),11,13-tetraene-3,5-dione (2b). Triflic anhydride $(1.0 \mathrm{~mL}, 5.9 \mathrm{mmol})$ was added drop wise to a solution of tropone $(1.2 \mathrm{~mL}, 12.0$ $\mathrm{mmol})$ in $25 \mathrm{~mL}$ of dichloromethane. After $5 \mathrm{~min}$ 5-phenylbarbituric acid (1.227 g, $5.9 \mathrm{mmol})$ was added and the mixture was gently refluxed for $11 \mathrm{~h}$. Then $10 \mathrm{~mL}$ of a $10 \%$ aqueous sodium carbonate solution were added and the organic layer was separated and washed twice with water. Upon addition of $200 \mathrm{~mL}$ of $\mathrm{n}$-hexane a dark brown solid precipitated which was filtrated and 
washed with $n$-hexane, water and finally acetone. Further purification was achieved by precipitation from DMSO/water. Pale brown solid (3\%); mp: $242-245{ }^{\circ} \mathrm{C}$ (decomp.); ${ }^{1} \mathrm{H}$ NMR $\left(500 \mathrm{MHz}, \mathrm{DMSO}-d_{6}\right): 4.80$ (ddd, $\left.J=2.0,2.0,2.9 \mathrm{~Hz}, 1 \mathrm{H}\right), 5.53(\mathrm{dd}, J=2.9,9.9 \mathrm{~Hz}, 1 \mathrm{H}), 6.20$ $(\mathrm{dd}, J=2.0,6.2 \mathrm{~Hz}, 1 \mathrm{H}), 6.24(\mathrm{ddd}, J=2.0,5.6,9.9 \mathrm{~Hz}, 1 \mathrm{H}), 6.47(\mathrm{dd}, J=6.2,11.0 \mathrm{~Hz}, 1 \mathrm{H})$, $6.51(\mathrm{dd}, J=5.6,11.0 \mathrm{~Hz}, 1 \mathrm{H}), 7.29(\mathrm{tt}, J=1.5,7.5 \mathrm{~Hz}, 1 \mathrm{H}), 7.39(\mathrm{tt}, J=1.5,7.5 \mathrm{~Hz}, 2 \mathrm{H})$, $7.45(\mathrm{dt}, J=1.5,7.5 \mathrm{~Hz}, 1 \mathrm{H}), 11.47$ (bs, $1 \mathrm{H}) ;{ }^{13} \mathrm{C}$ NMR (63 MHz, DMSO-d6): 55.9, 90.9, $100.0,119.4,124.8,126.5,126.9,127.9,128.0,129.7,129.8,142.3,146.7,157.4$, 163.7; ESIMS (\%): $293(100)[\mathrm{M}+\mathrm{H}]^{+}$.

\section{Acknowledgements}

Financial support by the Deutsche Forschungsgemeinschaft is highly appreciated.

\section{References}

1. Bailey, J.; Elvidge, J. A. J. Chem. Soc., Perkin Trans. 1 1973, 823.

2. Chen, X.; Tanaka, K.; Yoneda, F. Chem. Pharm. Bull. 1990, 38, 307.

3. Breilinger, E.; Niemz, A.; Rotello, V. M. J. Am. Chem. Soc. 1995, 117, 5379.

4. Takayasu, T.; Mizuta, Y.; Nitta, M. Heterocycles 2001, 54, 601.

5. Pontillo, J.; Chen, C. Bioorg. Med. Chem. Lett. 2005, 15, 1407.

6. Undheim, K; Benneche, T. In Comprehensive Heterocyclic Chemistry II; Katritzky, A. R.; Rees, C. W.; Scriven, E. F. V., Eds.; Pergamon: Oxford, 1996; Vol. 6, pp 93-231.

7. Bruno, O.; Schenone, S.; Ranise, A.; Bondavalli, F.; Barocelli, E.; Ballabeni, V.; Chiavarini, M.; Bertoni, S.; Tognolini, M.; Impicciatore, M. Bioorg. Med. Chem. 2001, 9, 629.

8. Melik-Ogandzhanyan, R. G.; Khachatryan, V. E.; Gapoyan, A. S. Russ. Chem. Rev. 1985, 54, 262.

9. Majumdar, K. C.; Sinha, B.; Maji, P. K.; Chattopadhyay, S. K. Tetrahedron 2009, 65, 2751.

10. Deady, L. W.; Ganakas, A. M.; Ong, B. H. Aust. J. Chem. 1989, 42, 1029.

11. Edstrom, E. D.; Yuan, W. Tetrahedron Lett. 1991, 32, 323.

12. Spange, S.; Bauer, M.; Walfort, B.; Lang, H. J. Org. Chem. 2006, 71, 7850.

13. Tietze, L.; v. Kiedrowski, G. Tetrahedron Lett. 1981, 22, 219.

14. Bolz, I.; Moon, C.; Enkelmann, V.; Brunklaus, G.; Spange, S. J. Org. Chem. 2008, 73, 4783.

15. Stang, P. J.; Maas, G.; Smith, D. L.; McCloskey, J. A. J. Am. Chem. Soc. 1981, 103, 4837.

16. Feith, B.; Weber, H.-M.; Maas, G. Liebigs Ann. Chem. 1986, 2123.

17. Gooßen, L. J.; Paetzold, J.; Briel, O.; Rivas-Nass, A.; Karch, R.; Kayser, B. Synlett 2005, 275.

18. Fanghänel, E. et al. Organikum, Wiley-VCH: Weinheim, 22 ${ }^{\text {nd }}$ edition, 2004, pp 233-234.

19. Nicolas, M.; Fabre, B.; Marchand, G.; Simonet, J. Eur J. Org. Chem. 2000, 1703. 